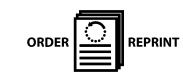

CHRONOBIOLOGY INTERNATIONAL

Vol. 20, No. 4, pp. 593-616, 2003

\title{
Nonvisual Photoreceptors in Arthropods with Emphasis on Their Putative Role as Receptors of Natural Zeitgeber Stimuli
}

\author{
Gerta Fleissner* and Günther Fleissner
}

Zoological Institute, J. W. Goethe-University Frankfurt a. M.

Frankfurt a. M., Germany

\begin{abstract}
“... Clearly more work will be necessary before truly informed judgements can be made about the functional significance of the diversity in photoreception for entrainment. A first step will be the precise identification of photoreceptors and investigations of the mechanisms of transduction, processing and transmission of temporal information provided by the daily light cycle..."

(Page, 2001)
\end{abstract}

\begin{abstract}
In various insect and arachnid species, three different types of photoreceptors that do not serve image processing have been discovered and analyzed by means of neurobiological methods: They can be found for example: (1) as lamina and lobula organs (LaOs and LoOs) next to the optic neuropils in the optic lobes of holo- and hemimetabolous insects; (2) inside the last ganglia of the cord of the scorpion and a marine midge; and (3) as modified visual photoreceptors in metamorphosized larval stemmata and the lateral eyes of scorpions, which have been compound eyes in fossil scorpion relatives. Immunocytology with various antibodies against proteins of the phototransduction cascade, the rhabdom turnover cycle and neurotransmitters of afferent and efferent pathways, was combined with light- and ultrastructural investigations in well-defined adaptational states, in order to study their photoreceptive function and neuronal wiring. Pilot chronobiological experiments with a newly developed
\end{abstract}

*Correspondence: Gerta Fleissner, Zoological Institute, J. W. Goethe-University Frankfurt a. M. Siesmayerstr. 70, D-60054 Frankfurt a. M., Germany; Fax: 0049-6039-41629; E-mail: fleissner@ zoology.uni-frankfurt.de. 
twilight simulating lamp, behavioral studies, and model calculations provide evidence that these photoreceptors may well serve a role in the complex task of detecting time cues out of natural dawn and dusk.

Key Words: Circadian clock; Circatidal rhythm; Extraretinal photoreceptor; Ocelli; Stemmata.

\section{INTRODUCTION}

It is still an unsolved problem how synchronization of circadian clock systems in arthropods is achieved, both with respect to receptors as well as concerning details of pathways and controlling systems - on different organizational levels. This still holds true for nearly all model organisms currently investigated, and for the different components of the multiple oscillator system, which may be entrained by photic or nonphotic Zeitgeber stimuli. This lack in understanding Zeitgeber processes obviously has several reasons: the receptors are unknown, the relevant, i.e., species-specific timing cues in the natural surroundings are widely ignored, and adequate tests for synchronization are unavailable. Reduced laboratory conditions with often uniform on/off light programs and single parameter rhythms (e.g., locomotor activity) have provided insight into formal mechanisms of external synchronization and phase setting (Daan and Aschoff, 2001). But such simplified paradigms have the disadvantage in that the complex timing processes and component parts of multiple oscillators in an organism and its ecological needs can hardly be recognized. Basically, light stimuli to all photoreceptors may induce phase shifts, possibly via the photic (e.g., for extraretinal photoreceptors: Bennett, 1979), but also via nonphotic pathways, when the organism is aroused by light input (Fleissner et al., 1989). On the other hand, the slow twilight transition during dusk and dawn, approved as the most effective natural timing cue (Boulos et al., 1996a; Fleissner and Fleissner, 1998; Lüttgen, 1993) can only be sensed either by specialized "nonvisual" photoreceptors (Menaker, 1982; Nelson and Takahashi, 1991) or by a combined network of different photoreceptors and/or specialized neuronal wiring (Fleissner and Fleissner, 1998). Thus, the testing for the Zeitgeber receptor function should be focused on the ability to perceive natural twilight transitions, not only on the phase shifting power of on/off light pulses to single photoreceptors. Our investigations on the neural basis of seeing time in arthropods aimed on several aspects: (a) study of complex behavioral rhythms under timing conditions in the field and in simulated quasi natural laboratory conditions; (b) analysis of the entity of all photoreceptors, which are not involved in image processing; (c) revealing the afferent and efferent innervation of these time-eyes, especially concerning their neuronal and humoral connection to the circadian pacemaker.

Image processing photoreceptors (e.g., compound eyes and dorsal ocelli ${ }^{\mathrm{a}}$ of insects, median eyes of scorpions, lateral eyes of Limulus) in arthropods all seem to be of similar

aIn literature, the term "ocellus" is used with different meanings: (1) the general construction plan of a photoreceptor with one corneal lens in contrast to a "compound eye" with a multitude of densely packed tiny corneal lenses; (2) the (dorsal) ocelli of insects with well-defined target zones of their receptor afferents in the midbrain area; (3) the (larval) ocelli of holometabolous insects, also named stemmata, which also have the ocellar shape. They have their first neuropils in the optic lobes. 


\section{$-7$}

origin and basic cellular construction plan, while nonvisual photoreceptors may have a different phylogenetic history. Basically due to the site of their photoreceptive cells, three types of nonvisual receptor organs can be classified: Type 1 receptors lie in the optic lobes; Type 2 receptors can be found inside the ventral nerve cord; Type 3 receptors are eyes, which still are organized as retinal receptors, but have more or less lost their image processing ability. They obviously may serve nonvisual functions as radiation meters and time processing devices.

In a few cases of these nonvisual photoreceptors, electrophysiological data showing light-induced changes of the receptor potential or nervous discharge are available (none for Type 1 receptors; for Type 2 receptors: e.g., Geethabali and Rao, 1972; Zwicky, 1968; for Type 3 receptors: e.g., Fleissner, 1985). Most evidence for photoreceptive function is derived from immunohistochemistry or structural changes caused by light. All of these nonvisual receptors seem to have a molecular and subcellular structural basis for phototransduction similar to that of visual receptors, and thus can be investigated by principally the same neurobiological method. ${ }^{\mathrm{b}}$

There are additional nonvisual photoreceptors all over the arthropod's body, which we will not review here in detail. (a) "Brain photoreceptors": Physiological and chronobiological experiments on circadian and photoperiodic timing have clearly shown a role of a light sense in this part of the central nervous system. The earliest known are experiments on moth pupae conducted by Truman, who succeeded to transplant pacemaker and light input (for review: Truman, 1976). In crayfish, next to the antennal base, photoreceptor organs are described and neurobiologically investigated (Sandeman et al., 1990). By immunostaining with antibodies against the phototransduction cascade, brain neurons could be marked (e.g., Cymborowski and Korf, 1995; Gao et al., 1999). These scattered immunoreactive cells are neither found to form a discrete photoreceptor organ nor to occur in reproducible sites. (b) Photosensitive glands: Several glands receive information on external light programs via direct photosensitivity of glandular cells, which obviously may serve as independent peripheral clock systems. The circadian regulation of release of prothoracic hormone from the retrocerebral complex (or prothoracic gland) and its photic control can be mimicked in vitro (in Rhodnius prolixus: Vafopoulou and Steel, 1996; in Samia cynthia: Mizoguchi and Ishizaki, 1984). Other glands like testis and excretory organs also seem to be light sensitive, and their circadian rhythm may be phase-shifted when isolated from the body (testis: Gielbultowicz et al., 1988; 1989; Malpighian tubules: Hege et al., 1997). Possibly many more organ systems in arthropods may turn out to house an independent photoreceptive clock, as has been demonstrated for Drosophila (Plautz et al., 1997).

It is premature to speculate about the latter systems as component parts of the entraining mechanisms of the central circadian clock system, especially concerning

\footnotetext{
${ }^{\mathrm{b}}$ Methods and Experimental Animals: Our studies are mainly based on desert beetle and scorpion species as model organisms, selected for their robust endurance of extreme climatic conditions by strict nocturnality and sometimes weeks or months of subterranean lifestyle - self-selected constant DD conditions without food and water intake. These results have lead us to successful comparative neurobiological studies in cockroaches, crickets, grasshoppers, and marine midges, all wellestablished model systems in chronobiological research. Neurobiological methods have been adapted to serve the special needs of the project work (Fleissner et al., 2001a; Schuchardt et al., 2002; Thomas et al., 2003). Immunocytological investigations with partly noncommercial antibodies mainly followed protocols of B. Battelle (St. Augustine, USA) (Battelle et al., 2001).
} 
synchronization under natural conditions. Therefore, we will focus our review on our data ${ }^{c}$ and parallel findings of other teams on the three types of nonvisual photoreceptors mentioned above, which have led to hypotheses on the detection of timing cues during dusk and dawn and serve both, the external and internal synchronization of the arthropod circadian clock system.

\section{Type 1 Nonvisual Photoreceptors in the Optic Lobes of Insects}

\section{Occurrence}

Type 1-photoreceptors have been found in hemi- and holometabolous insect orders [e.g., Carabid beetle Pachymorpha (Anthia) sexguttata (Fleissner et al., 1993a) Tenebrionid beetle Zophobas morio (atratus) (Fleissner et al., 1998), Scarabid beetle Melolontha melolontha (Fleissner, unpublished), Hymenoptera Vespa spec. (Fleissner, unpublished), Orthoptera Teleogryllus bimaculatus (Fleissner, unpublished), Blaberus craniifer and Leucophaea maderae (Fleissner et al., 2001)]. They are distinct from all other insect photoreceptors, so far known. Throughout the entire larval, pupal, or adult stages, Type 1 receptors lie within the optic lobes [Fig. 1(A)]: Already in the earliest larval stages, Type 1 photoreceptor organs can be found near the "optische Anlagen." During metamorphosis, when the optic ganglia alter their neuronal organization, shape, size, and site, the Type 1 receptors always stay next to the lamina and lobula, the first and third optic neuropil [Fig. 1(B), (C)] (Fleissner et al., 1994). Therefore, they are named lamina organ $(\mathrm{LaO})$ and lobula organ $(\mathrm{LoO})$, respectively. The $\mathrm{LaO}$ lies on the proximal dorso-frontal rim of the compound eye lamina (LA), the $\mathrm{LoO}$ on the distal medio-frontal rim of the lobula (LO).

Further neurobiological investigations are necessary to determine whether the so called "blue-light photoreceptors," described in Drosophila by cryptochrome-immunoreactivity next to the assumed circadian pacemaker site, could be modifications of these Type 1 photoreceptors, too (for review: Helfrich-Foerster and Engelmann, 2002).

\section{Size and General Appearance}

Lamina and lobula organs do not have shielding pigment, which makes them "invisible" without specific staining or optical methods [Fig. 1(D)-(F)]. The diameter of these organs is always close to $30-50 \mu \mathrm{m}$, and the length ranges from $80 \mu \mathrm{m}$ to more than $400 \mu \mathrm{m}$, depending on species and developmental stage (Fleissner et al., 1994; 2001). They are of elongated shape, slightly bent, and resemble a single huge ommatidium with multiple receptor cells forming a common rhabdom-like microvillar complex in the center of the organ. In cross sections, the organs may have a round or prominent horseshoe-like appearance (Fleissner et al., 1993a).

\footnotetext{
${ }^{\mathrm{c}}$ The paper is part of a progress report on projects funded by the DFG priority program.
} 


\section{ORDER}

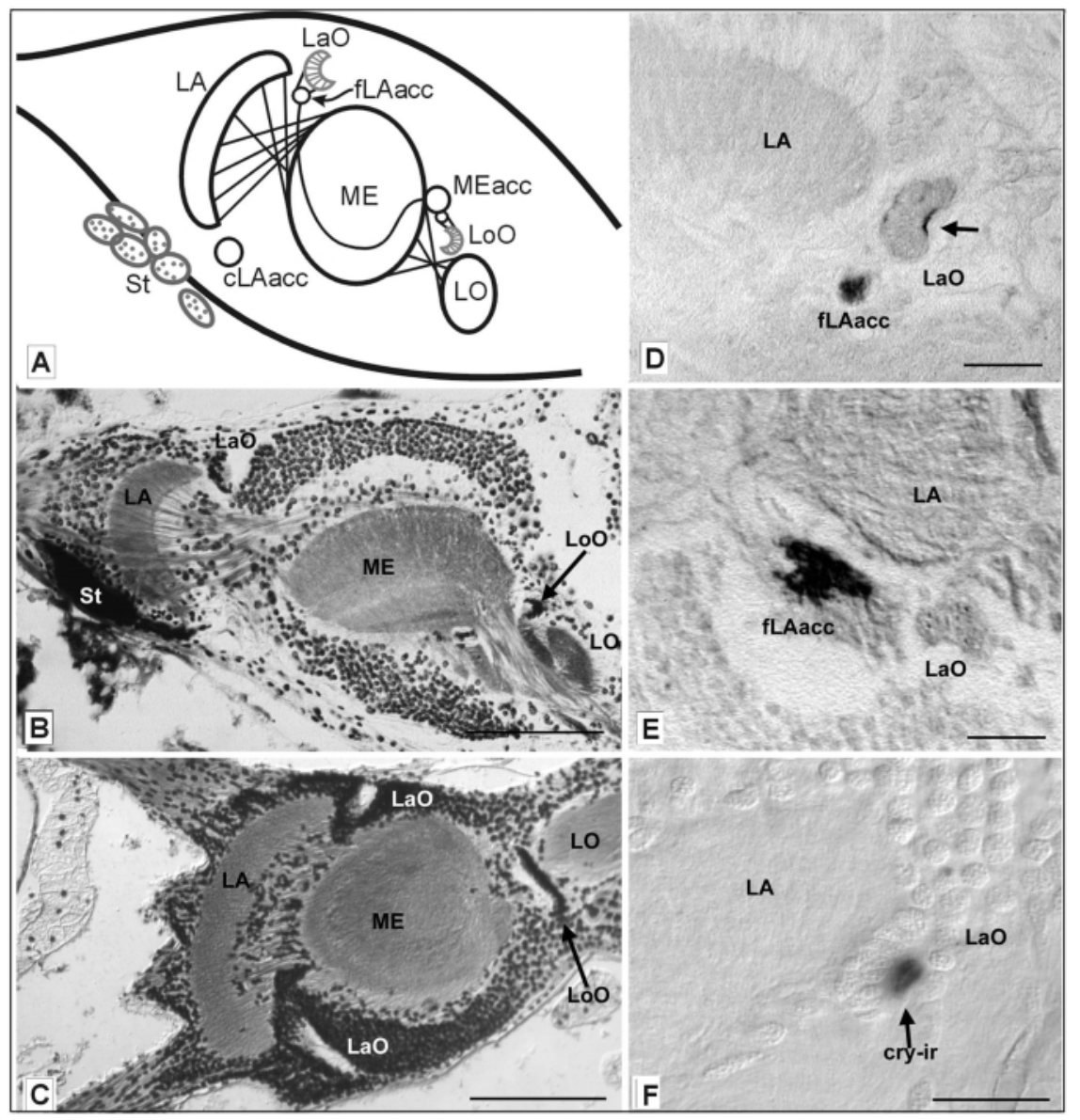

Figure 1. Type 1 nonvisual photoreceptors in the optic lobes of insects. (A) Scheme showing the site of the $\mathrm{LaO}$ next to the frontal rim of the $\mathrm{LA}$, and the $\mathrm{LoO}$ between $\mathrm{LO}$ and ME. The elongate organs always can be found near the optic chiasms. (B) and (C) Longitudinal sections through the optic lobe of a pupa of the Tenebrionid beetle Z. morio (B) and a late nymphal stage of the cockroach Blaberus craniifer (C). As the organs have a bent shape, they are partly seen in cross section (B) or cut at both ends ( $\mathrm{LaO}$ in $\mathrm{C}$ ). (D) to (F) Horizontal sections through the optic lobes of the Carabid beetle P. sexguttata (D and E) and the cockroach L. maderae (F). (D) Immunostaining with an antibody against $\mathrm{C} 10 \mathrm{C} 10$ (part of the arrestin protein). The microvilli seam of the photoreceptor cells and the little fLAacc, where the receptor axons have their first afferent endings marked. (E) An antibody raised against a Drosophila Per protein reacts with scattered efferent terminal endings inside the $\mathrm{LaO}$ and provides a dense staining in about half of the fLAacc. From here axons connect to the MEacc, the site of the circadian pacemaker. (F) Only in the $\mathrm{LaO}$ and $\mathrm{LoO}$ (not shown here) of the cockroach, an antibody against Arabidopsis cryptochrome reacts with core cells in the center of the organs. The receptor cells themselves are not cry-immunoreactive. Key: cLAacc, caudal lamina accessoria of the stemmata (St); fLAacc, frontal lamina accessoria; LA, lamina; LaO, lamina organ; Lo, lobula; LoO, lobula organ; ME, medulla; MEacc, medulla accessoria; St, stemmata; arrows in (B) and (C) point to LoO; arrow in (D) points to arrestin-immunorecativity of microvilli; arrow at cry-ir pints to cryptochrome immunoreactive core of the $\mathrm{LaO}$. Scale in $\mathrm{B}=100 \mu \mathrm{m}$, in $\mathrm{C}=200 \mu \mathrm{m}$, in $\mathrm{D}$ and $\mathrm{E}=30 \mu \mathrm{m}$, in $\mathrm{F}=40 \mu \mathrm{m}$, A not to scale. 
General Receptor Cell Structure

The receptor cells are closely attached to each other, and, unlike the neighboring neurons, are not separated by intercalated glial cells. A slim nucleus and a long trunk ending in untidy rhabdom-like microvilli, which increase after dark-adaptation (Fleissner et al., 1993a; 1998), a large number of tiny microvilli in the trunk next to the microvillar seam, and densely packed ribosomes further characterize these cells (beetles: Fleissner et al., 1993a; cockroaches: Fleissner et al., 2001). This dense cytoplasm makes the receptor cells especially susceptable to vital stainings such as methylene blue, and thus detectable for physiological studies (Fleissner et al., 2001). The organ cells, especially the microvilli, can be marked by immunostaining with antibodies against various proteins of the phototransduction cascade [Fig. 1(D), (E)] (Fleissner et al., 1993a), which can indicate that the organs are functional photoreceptors, which are especially sensitive to long wavelengths. Antibodies against UV and blue-green cone opsins did not mark the organ cells, which clearly showed up after staining with red-cone opsins (Fleissner et al., 1994).

Precursors of shielding pigment granules can be found in the cells surrounding the organ cells in the early pupal stages, but they never develop into a screening shield (Fleissner et al., 1994).

\section{Specialized Organ Cells}

In all the investigated LaOs and LoOs, the cells basically look the same, irrespective of insect order or instar. But in some cases we have found additional, obviously nonphotoreceptive cells in early larval stages of cockroaches and beetles, and especially in pupae and adults of Tenebrionid beetles. These organ cells do not have a microvillar seam, but instead a subcellular structure typical for glandular cells (Fleissner et al., 1993b) - stacks of rough endoplasmic reticulum and multiple vesicles, shown by impregnation (Buma et al., 1984) to be exocytotic, provide evidence for a neuroendocrine function (see below). These glandular cells gather in a certain part of the $\mathrm{LaOs}$ and LoOs and do not react with photoreceptor-specific antibodies, e.g., arrestin and opsin. After dark-adaptation, in nocturnal optic lobes, these compartments proliferate and show intensive reactivity with anti-5HT antibodies and precursors (Fleissner et al., 1995; 1998).

Another additional cell type could be found in the organs of cockroaches (Fleissner et al., 2001); in the center of the ommatidial structure, about 15 slim cells with extremely large nuclei expand perpendicular to the receptor cells. These large cells excrete a fluffy substance, which condenses extracellularly to a stick-like core, stainable with an antibody against Arabidopsis cryptochrome, an assumed essential component of photic entrainment [Fig. 1(F)] (for review of cryptochrome meaning in Drosophila: HelfrichFoerster and Engelmann, 2002). Derived from its ultrastructure and site, this component cannot play a photoreceptive function in cockroaches.

\section{Neuronal Wiring}

On their proximal end, the cells of the $\mathrm{LaO}$ have axons, which form a common optic tract and terminate in a separate first optic neurophil, the frontal lamina accessoria (fLAcc) 


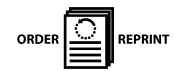

Nonvisual Photoreceptors in Arthropods

(Fleissner et al., 1993a; Frisch et al., 1996). This neurophil is clearly distinct from the huge compound eye lamina (LA) and the caudal lamina accessoria (cLAcc) of the stemmata, one for each of the six stemmata. Less clear is the first terminal region of the LoO, which might be fused with the medulla accessoria (MEacc), in holometabolous insects, the second neurophil of the stemmata. The afferent axons and terminals in the first neuropils of the LaOs and LoOs stain with antibodies against histamine (Fleissner et al., 1994), as is known from arthropod photoreceptors in general (Nässel et al., 1988), and an antibody against $\mathrm{G} \alpha \mathrm{q}$, a protein part of the phototransduction cascade (Fleissner and Schuchardt, unpublished). The organ cells also receive efferent input (electron microscopic investigation in cockroaches: Fleissner et al., 2001, beetles: Fleissner et al., 1993a). In beetles, these terminals might at least partly originate from neurons innervating the accessory medulla, as could be shown by immunostaining with an antibody raised against the Drosophila Per protein [Fig. 1(E)] (Fleissner et al., 1993a; Frisch et al., 1996). In cockroaches, efferent innervation from the MEacc was also made possible; immunostaining with antiG $\alpha$ q antibodies clearly showed tiny accessory LAs as in beetles within the first optic chiasm (Fleissner and Schuchardt, unpublished). The same structures have been described previously in another context; by tracing light-responding neurons of the accessory medulla of cockroaches, small neuropils at the proximal rim of the LA stained (Loesel and Homberg, 2001).

Putative Function of the Optic Lobe Photoreceptors

These structural and immunocytological findings, combined with electrophysiological studies in cockroaches (Loesel and Homberg, 2001) and pilot chronobiological long-term recordings in beetles, indicate that these organs are likely a part of the photic Zeitgeber input of the circadian clock system. In combination with other photoreceptors, they may provide a complex sensor for perceiving time cues from natural twilight transitions (see Type 3 photoreceptors).

Additionally, they may, through their glandular compartments, serve a photoneuroendocrine function. Modulating information processing in the optic pathway of beetles or in larvae, they may even serve photomorphogenesis by informing on external light/dark cycles, before retinal photoreceptors have been shaped or neuronally connected to the optic neuropils.

\section{Type 2 Nonvisual Photoreceptors in the Ventral Nerve Cord}

In the ventral nerve cord, we have found candidate structures that seem to mediate the metasomal light sense of scorpions [shown by electrophysiological recordings (Geethabali and Rao, 1972; Zwicky, 1968)] and perhaps component parts of the "moonlight receptor" in marine midges, which is deduced as an essential component of their complex endogenous circa-lunar control system for metamorphosis and eclosion (Neumann, 1989). Though still less elaborate than Type 1 receptors, presumably both putative Type 2 photoreceptors are similar in shape and location in the ventral nerve cord [Fig. 2(A)], and therefore reviewed here in the same section. 


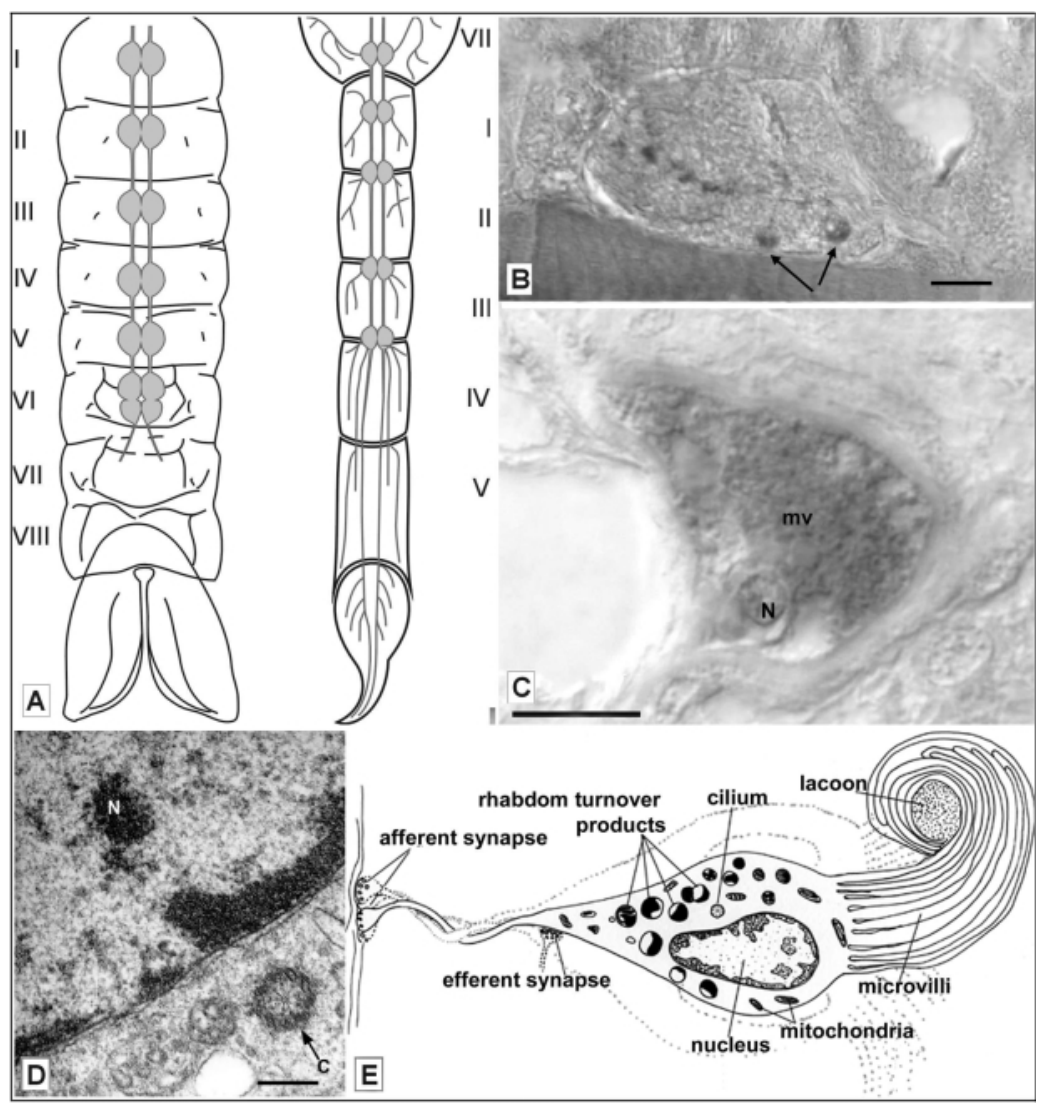

Figure 2. Type 2 nonvisual photoreceptors in the ventral nerve cord of arthropods. (A) Scheme of the abdomen of a marine midge Clunio (left side) and a scorpion Paruroctonus (right side) showing the site of the segmental ganglia and main neuronal connections of the ventral nerve cord. (B) Sagittal section of a 7th abdominal ganglion of Clunio stained with an antibody against bovine bluecone-opsin. On each side two cells can be marked with short axons ending in a neuropil near the frontal rim of the same ganglion. (C) Soma of a putative photoreceptor cell in the last metasomal ganglion of Paruroctonus after dark adaptation, stained by an antibody against arrestin (part $\mathrm{C} 10 \mathrm{C} 10)$, a protein of the phototransduction cascade. The nuclear region is "coronated" by a large bundle of microvilli (mv), which are encapsulated by a sheath. (D) Electron microscopic view of the scorpion putative metasomal photoreceptor. Next to the nucleus a cilium (arrow at C) can be found like known from e.g., the annelid dermal light sense or sauropsid pinealocytes. (E) Scheme of a photoreceptor cell of the scorpion metasomal light sense as reconstructed from serial TEM sections. Often two or three cells of similar fine-structure lie together ending in the same terminal region. Key: C, cilium; mv, microvilli; N, nucleus; I to VIII in (A) indicate segmental numbers; arrows in (B) point to stained somata; arrow in (D) points to cilium; scale bar in $B=15 \mu \mathrm{m}$, in $\mathrm{C}=10 \mu \mathrm{m}$, in $\mathrm{D}=0.2 \mu \mathrm{m},(\mathrm{A})$, and (E) not to scale. 


\section{General Occurrence}

Both electrophysiological and chronobiological studies have proposed a metasomal light sense in scorpions and the horseshoe crab Limulus, ${ }^{\mathrm{d}}$ an arachnid like the scorpion. But so far, the structure and neuronal wiring of the photoreceptors in the metasoma are unknown.

Probably, light sensitivity of peripheral neurons, e.g., in the last ganglia of the ventral nerve cord, must be assumed as a widespread, basic feature of neuronal photosensitivity in arthropods, which has been studied in a few species of insects and crustacea as putative photic input to the circadian pacemaker (cockroach: Ball, 1965; 1972; crayfish: BernalMoreno et al., 1996; Edwards, 1984; Hama, 1961; Kennedy, 1958). The most investigated is the genital light sense of butterflies with its first photoreceptor terminals in the last abdominal ganglion, which has definitely no timing function in the circadian system (Miyako et al., 1993; Arikawa, 1999).

We can, for the first time, describe structural candidates of the metasomal light sense in the scorpion and marine midge. We have found specialized receptor structures and neuronal pathways, allowing us to hypothesize on their ability to see natural Zeitgeber stimuli. What do these receptors look like?

\section{Size and General Appearance}

So far, we have found promising candidate receptor cells only in the midge and in the scorpion, and analyzed the details of their structure. There is no closed organ as in the Type 1 or Type 3 photoreceptors, but instead bilateral groups of two to three cells in the caudo-ventral part of the most caudal ganglia [Fig. 2(B)]. Their somata are about $5 \mu \mathrm{m}$ in diameter and lie close to each other near the surface of the neuronal mass inside the neurilemma. They have no shielding pigment, but a vacuole-like lumen in the midst of the rhabdom-like microvilli mass [Fig. 2(C), (E)] (Schuchardt et al., 2002). In the light microscope, these cells, like the Type 1 receptors, cannot be found without specific staining. Therefore, it will be very difficult, if not unlikely, to record from these cells intracellularly: all the reported light-induced reactions originate from extracellular recordings (Geethabali and Rao, 1972; Zwicky, 1968; 1970).

\section{Receptor Cell Structure}

The putative receptor cells can be marked by antibodies against proteins of the phototransduction cascade [Fig. 2(B), (C)]. All tested antibodies stained similar cells in both organisms, a hint to functional light sensors. In scorpions we have finished a first series of electron microscopic studies and thus can describe fine structural details from this

\footnotetext{
${ }^{\mathrm{d} B e t t e r}$ analyzed and often described are the other visual and nonvisual systems of both arachnids. The visual receptors are the median eyes in scorpions, and the lateral compound eyes in Limulus. Nonvisual receptors are the lateral eyes of scorpions (Fleissner, 1977c) and a complex set of receptors in Limulus: "median ocelli," a set of ventral photoreceptors, and a rudimentary lateral eye next to the lateral compound eyes may serve as photic Zeitgeber receptors (for review: Renninger and Chamberlain, 1993). The sensitivity of all these visual and nonvisual photoreceptors in both model systems is clock controlled by efferent fibers and all can separately phase-shift the clock (for further details see below: Type 3 photoreceptors).
} 
organ [Fig. 2(D), (E)]. The somata are coronated by rather long, untidily arranged rhabdom-like microvilli, which appear enlarged after dark-adaptation. Turnover products, multivesicular, multilamellate bodies, and secondary lysosomes also change their number and appearance according to the adaptational state, as is known from other invertebrate photoreceptors (Schwemer, 1985). A protein from the photoreceptor second messenger complex, $\mathrm{G} \alpha \mathrm{q}$, and a component part of the enzymatic engine for rhabdom membrane cycling, Myosin III, could be recognized in these receptor cells by immunostaining (Schuchardt et al., unpublished) (in Limulus: Battelle et al., 2001).

Most striking and unusual for insect or arachnid retinal photoreceptors, is an intracellular cilium [Fig. 2(D)]. This structure indicates that these cells may stem from epidermal hair sensilla. In annelids, for example, photoreceptors also have both rhabdomlike microvilli and a cilium, which might occur as intracellular structures only or, after dark-adaptation, protrude into the extracellular space (for review: Yoshida, 1979). Similar "primitive" photoreceptors in vertebrates are well known as pinealocytes of birds and turtles (for review: Korf, 1994).

\section{Neuronal Wiring}

The receptor cells have short axons, which end in a nearby ipsilateral terminal region inside the same ganglion. They are histaminergic, as are the secondary neurons, which connect to the first receptor neuropils (Schuchardt et al., 2002). These secondary neurons obviously belong to a set of histaminergic fibers that extend through the entire ventral nerve cord. They may give rise to the light-induced action potentials recordable from the connectives after exposing only the last two ganglia to light, and may also be the signaling pathway for the reported arousal reaction, a flip-reflex of the sting after light input to the tail (Geethabali, 1974; Zwicky, 1970).

Additionally, efferent fibers innervate the receptor cells close to their axonal terminals. Immunostainings and neurosecretory synapses in the TEM studies provide some evidence for a serotonergic innervation.

\section{Putative Function of the Ventral Nerve Cord Photoreceptors}

The Type 2 photoreceptors inside the ventral nerve cord can hardly serve spatial orientation, and in midges and scorpions they seem to be color-blind with only one photopigment, ascertained electrophysiologically for the scorpion (Fleissner, 1968; 1974; Geethabali, 1974) and immunohistologically for both systems (Schuchardt et al., 2002). Mainly three different problems of natural timing could be solved by means of these receptors:

1. Discrimination of periodic solar and lunar light cycle. Recordings in dark-adapted scorpions after moderate light stimuli on the tail showed normal and retarded reactions (Geethabali, 1974), indicating that they sense low and slow changes of environmental light. In combination with the retinal photoreceptors, these Type 2 receptors may serve to discriminate the different dynamics of dawn and dusk, of rising and setting moon, and of accidental shading by clouds and vegetation (see below). Thus, they may provide a set of information to either monitor the lunar cycle, as moonlight receptor of the midges, or, in 


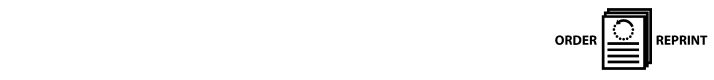

the case of the scorpion, help to avoid moonlight exposure and gain temporal information from dusk only.

2. Modulation of receptor sensitivity. In insects, it has been shown that light to ocelli may modulate the sensory threshold of compound eyes (Goodman, 1981; and see below in Type 3 photoreceptors). A similar effect may hold true for Type 2 receptors in scorpions and midges. In Limulus, additional light to the metasoma increased the sensitivity of the circadian system to photic Zeitgeber input via the lateral or median eyes (Hanna et al., 1985).

In midges, moonlight exposure has a dramatic effect during a well-defined larval instar (for review: Neumann, 1989). Only in this short timespan, a moonlight receptor, which is shown to be modulated in a circadian way, can help to synchronize with the lunar rhythm. The compound eyes are not yet developed, and the larval eyes show no structural specializations or neuronal pathways indicating an additional function as moonlight receptors. We, therefore, speculate that in Clunio, the receptor cells in the ventral nerve cord together with retinal photoreceptors may provide a complex network information to recognize moonlight dynamics as time cues for developmental processes. Further experiments will have to explore this gated tuning effect (see also below).

3. Control of arousal stimuli as nonphotic Zeitgeber input. In scorpions, we could demonstrate that light stimuli may evoke hyperactivity, which can phase-shift the circadian rhythm via a nonphotic pathway, and that they underlie a paradoxical phase-responsecurve different from the general photic one (Fleissner and Fleissner, 2001b). Light stimuli to the median eyes and to the metasoma sometimes evoked an arousal reaction, but this never happened with light to the lateral eyes. Arousal with an underlying light stimulus is by far more effective than arousal alone. It is not yet investigated whether light input to the metasomal photoreceptors serves as an essential control step to recognize a nonphotic Zeitgeber input.

\section{Type 3 Nonvisual Retinal Photoreceptors}

Retinal photoreceptors are not necessarily image processing sensors. In several cases it could be shown that either by the reduction of the dioptric apparatus, by obscuring ommatidial organization, or by neuronal integration, these retinal receptors have almost lost spatial resolution, which is essential for image processing. Rather, they serve as radiation meters, integrating light input over space and being sensitive to successive contrast. In many textbooks these eyes are called "reduced" or "rudimentary," though they have simply evolved to serve another function, seeing time instead of seeing images, and now are essential for temporal rather than spatial orientation.

The dorsal ocelli of insects, which are widely distributed in many insect orders, may serve a nonvisual function. Being faster and more sensitive than the compound eyes, they may influence the threshold of the compound eyes, serve flight control (Sprint and Eaton, 1987), and also modulate the freerunning rhythm (Wunderer and De Kramer, 1989; for review see: Mizunami, 1995). On the other hand, they are reported to be indispensable for circadian clock entrainment (for review see: Page, 2001). In scorpions, the median eyes are basically visual photoreceptors. But via a special wiring they may also serve a nonvisual 


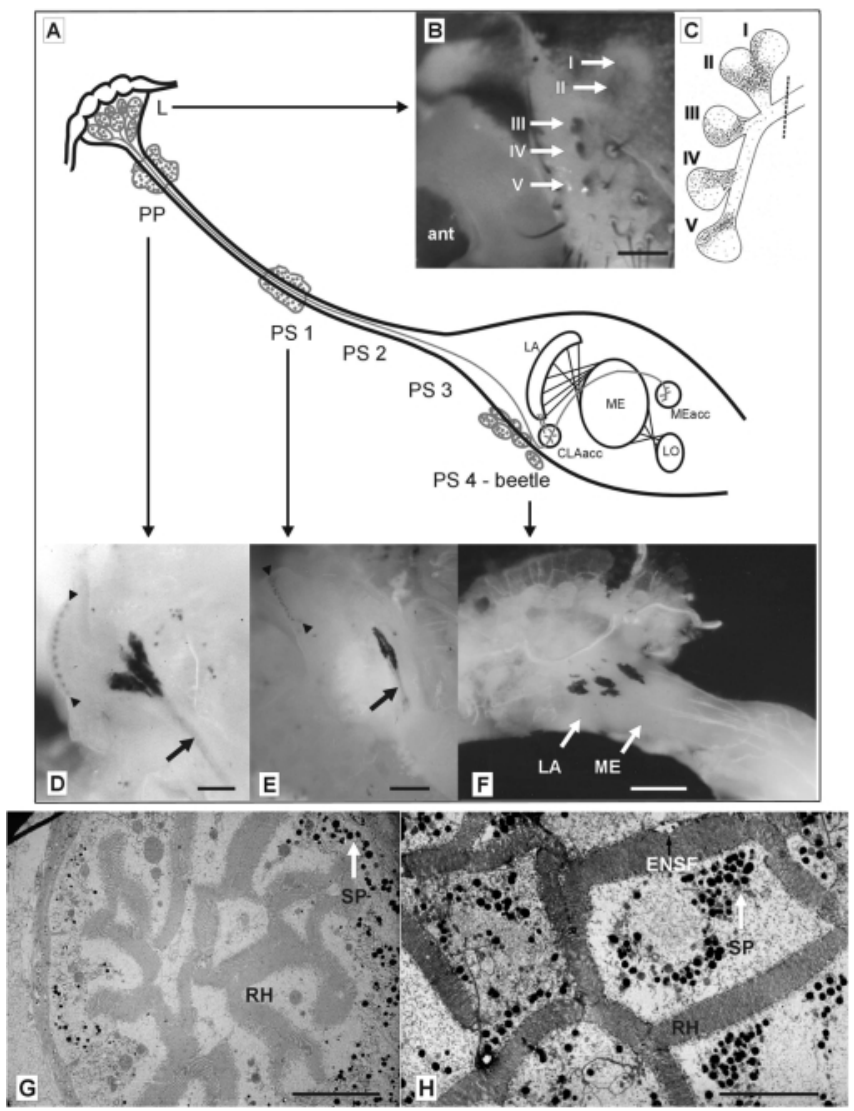

Figure 3. Type 3 nonvisual retinal photoreceptors. (A) to (G) Metamorphosized larval stemmata of the Tenebrionid beetle Z. morio, $(\mathrm{H})$ lateral eye of the scorpion Androctonus australis. (A) Scheme of the invagination of the larval photoreceptors during metamorphosis and their neuronal connections, which is preserved during this process. In larvae (L) the retinal photoreceptors (B) and (C) may serve visual function as they are arranged as separate optical units (I to V). During pupation (PP) and further pupal development (PS1 to PS4) the stemmata loose their shape and "slide" into the head capsule towards their final site at the caudal rim of the optic lobe. (D) to (E) show typical aspects of the dissolving stemmata during pupal development marked by shielding pigment. $(\mathrm{G})$ and $(\mathrm{H})$ electron microscopic view of the rhabdom network of this type photoreceptor ( $G$ the larval stemmata, $\mathrm{H}$ scorpion lateral eye). The ommatidial arrangement of photoreceptors is optically replaced by fused rhabdoms, which can in principal serve as fiber light guide over the entire retina-a specialization towards lower intensity threshold and reduced spatial resolution. Key: ant, base of the antenna; RH, rhabdom; ENSF, profile of efferent neurosecretory fibers; arrows in B point to cuticular site of larval stemmata; arrows in (D) and (E) point to the optic nerve partly marked by migrating shielding pigment; arrow heads in (D) and (E) mark the developing compound eye retina; white arrows in (F) indicate site of the optic neuropils; white arrows in $(\mathrm{G})$ and $(\mathrm{F})$ point to shielding pigment granules inside the photoreceptor cells (see abbreviation in Fig. 1). Scale bar in $\mathrm{B}=200 \mu \mathrm{m}$, in $\mathrm{D}$ and $\mathrm{E}=100 \mu \mathrm{m}$, in $\mathrm{F}=200 \mu \mathrm{m}$, in $\mathrm{G}$ and $\mathrm{H}=10 \mu \mathrm{m}$. 


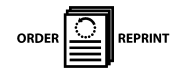

function. We will include both visual and nonvisual receptors below when we discuss hypotheses on twilight detection.

Here we mainly review two typical systems that have been investigated in detail by our laboratory - the stemmata of insects and the lateral eyes of scorpions.

Occurrence and General Appearance

1. Stemmata: Larvae of beetles, especially those with a predacious life style, have sets of image processing ocelli that serve detection of their prey (Gilbert, 1994). During pupation these larval ocelli or stemmata are internalized into the depth of the head capsule [Fig. 3(A)-(F)]. In the adult insect they can be found as heavily pigmented patches at various places on the optic lobes, most often at their caudal side. For example, in beetles, they may preserve their original entity, and appear as six separate internal eyes, or they fuse into an irregularly shaped assembly of shielding pigment and receptor cells that may even be different on left and right side optic lobes within the same individual (Tenebrionid beetles) [also in moths (Mischke and Ziegler, 1987)]. In adult insects, they never keep their dioptric apparatus or ommatidial structure, which would be essential for image recognition. Sometimes without relating these organs to larval eyes, stemmata, or their derivatives, the metamorphosized and internalized stemmata have been described in several insect orders as "brain photoreceptors" or "extraocular photoreceptors" (e.g., in ants: Felisberti and Ventura, 1996; in beetles: Mischke and Wellmann, 1985; Schultz et al., 1984; in butterflies: Mischke and Ziegler, 1987; Ichikawa, 1991; 1999; in caddiesflies: Hagberg, 1986; in flies: Seifert et al., 1987). Also, the Bolwig organ of Dipteran insects is a modified larval eye (Melzer and Paulus, 1989) and can be found in Drosophila as an "eyelet" in the compound eye's posterior margin (Hofbauer and Buchner, 1989; Yasuyama and Meinertzhagen, 1999).

Here we especially deal with the stemmata of two different beetle families, where we studied the circadian clock system: Carabid and Tenebrionid beetles.

2. The lateral eyes of scorpions: Another set of nonvisual retinal photoreceptors are lateral eyes of scorpions. Recent scorpions have several little ocelli on the fronto-lateral rim of the prosoma, which may occur in various numbers (five pairs or less) and size (about 200 to $50 \mu \mathrm{m}$ ) according to species and lifestyle. In fossil marine scorpions (Kjellesvig-Waering, 1986), these lateral eyes have been compound eyes, as can still be seen in recent close relatives, the horseshoe crab, Limulus. These formerly visual photoreceptors of scorpions have preserved a lens, but never have a vitreous, which could keep the retina in focus (Carricaburu, 1968). Still, they have their ommatidial organization left with all components that can be found in the visual median eyes. The median eyes are ocelli, too, but with a dioptric apparatus that focuses well and an ommatidial retina (for review see: Fleissner and Fleissner, 2001a; Locket, 2001). According to behavioral experiments lateral eyes serve spatial orientation to a lesser extent than the median eyes (Angermann, 1957).

\section{Receptor Cell Structure}

In both nonvisual retinal photoreceptors, insect stemmata and scorpion lateral eyes, the single receptor cells have no structural specializations, which cannot be found in the 
visual retinal receptors as well. They have rhabdomeric microvilli and contain the essential proteins from the phototransduction cascade, as can be shown by immunocytochemistry (Fleissner and Fleissner, 2001a). But as a specialty, their rhabdomeres build fused rhabdom networks, spreading over the entire retina [Fig. 3(H)] (Schliwa and Fleissner, 1980). Similar rhabdomeric networks as in the larval stemmata [Fig. 3(G)] have been reported from insect dorsal ocelli (Goodman, 1981). This structural feature provides maximized sensitivity to light intensity, but reduces spatial information. (1) Stemmata: During dark-adaptation the stemma rhabdoms may increase in volume and enhance their ability to catch every single photon. Their sensitivity changes in a circadian rhythm, but the amplitude may vary with developmental stages and cannot be determined in its absolute values (Waterkamp et al., 1998). It is nearly impossible to have noninvasive recordings from all parts of the stemmata patches, as the assembly of photoreceptor cells underlies individual changes, different for each single animal. (2) Scorpion lateral eyes: Electrophysiological measurements of scorpion lateral eyes have demonstrated a sensitivity threshold near the human scotopic vision (Fleissner, 1979a). Under control of the circadian clock, these eyes may increase their nocturnal sensitivity by 1 log unit (Fleissner, $1977 b, c)$, when the shielding pigment is placed in front of the rhabdoms. This circadian adaptation is low compared to that of the median eyes, which are about 10,000 times more sensitive during night than during day.

\section{Neuronal Wiring}

A putative function of these Type 3 photoreceptors as component parts of the photic Zeitgeber receptor system is based on the analysis of their afferent and efferent neuronal wiring.

1. Stemmata: The afferent optic fibers are histaminergic (Waterkamp et al., 1998), as in all arthropod photoreceptors. They are connected to two sets of neuropils (Fig. 3A). Each of the insect stemmata has its own first order optic neurophil, an accessory LA. These LAs are clearly distinct from the compound eye LA and lie at the caudal rim of the optic lobe. Parallel with the fusion of the stemmata in Tenebrionid beetles, the accessory LAs may fuse into one separate mass, but always stay separate from the compound eye LA. In Carabid beetles, all six stemmata keep their LAs separate, even when internalized in the adult insect. The second optic neurophil of all the stemmata afferent fiber is a common accessory medulla, a region between medulla and lobula, which has been found to be the probable site of the circadian pacemaker in beetles (Fleissner, 1982). Efferent fibers, which originate from cells at the proximal rim of the medulla, can be traced by immunocytochemistry with antibodies against 5-HT. In the compound eyes of beetles, serotonin has been analyzed as a putative circadian signal, which controls the shielding pigment migration and thus the photoreceptor sensitivity. Serotonergic fibers are widely spread over the entire LAs and can also be found distally, innervating the stemmata. Different from the $\mathrm{LaOs}$ and LoOs in beetles, the stemmata do not receive fibers immunoreacting with the Drosophila Per antibody.

2. Scorpion lateral eyes: Each of the lateral eye ommatidia is composed of 2-4 photoreceptor cells and one arhabdomeric cell, a light-insensitive first interneuron, postsynaptic to the photoreceptor cells (Fleissner and Siegler, 1978; Schliwa and 


\section{$-9-$}

Fleissner, 1979; 1980) and similar to the median eye ommatidia, each with five visual cells and one arhabdomeric cell, Such a retinal interneuron is described also in Limulus as an eccentric cell (Fahrenbach, 1975; Calman et al., 1991) These cells process image information directly to the second optic ganglion, the medulla, by nervous action potentials, while the photoreceptors only produce graduated receptor potentials (Fleissner, 1985) along their axons to the first optic ganglion, the LA. The arrhabdomeric cells of the lateral eyes may be the base for the reduced image information via these eyes (see above). All scorpion eyes receive efferent input from octopaminergic neurosecretory fibers, which serve as pathways of the circadian signal (Fleissner and Fleissner, 1985). The efferent fibers from lateral and median eyes are separate, but run parallel. Both systems originate from about five and more than 10 bilateral neurons, respectively. They branch into both sides of retinae, the LAs of the respective eyes, and the central body. The efferent fibers of the lateral eyes additionally innervate the median eye LAs. Due to a series of lesion experiments and histological controls, we know that these efferent fibers function as a "system bus" for circadian signaling, common for several effector systems, e.g., locomotor activity as well as sensory physiology (for review: Fleissner and Fleissner, 2001a).

\section{Putative Function of Type 3 Nonvisual Retinal Photoreceptors}

Unlike the Type 1 and Type 2 photoreceptors, Type 3 receptors can still play a limited role in image processing or spatial orientation. Their main function, however, seems to be processing of time. Experimental evidence for their function as photic Zeitgeber input comes from experiments in which light pulses are applied to individual photoreceptor. It is not astonishing that any light pulse induces phase-shifts and that light-dark programs can entrain the circadian rhythm (scorpion: Fleissner, 1977c; beetles: Koehler and Fleissner, 1978). But these experiments were conducted before chronobiological studies focused on natural Zeitgebers. Now we should rather discuss the putative contribution of a special photoreceptor system to a complex sensory network, which is able to detect time cues in dusk and dawn.

1. Stemmata: Different from the Type 1 photoreceptors in the optic lobes, the LaOs and LoOs, these stemmata sense shorter wavelengths (Waterkamp and Fleissner, unpublished) and can be stained with antiUV opsin and blue-cone opsin antibodies (Fleissner and Waterkamp, unpublished). This feature offers an attractive model, because during dusk and dawn the spectral composition of environmental light changes for a short period. During day and night the spectrum is the same but has a different intensity. Both nonvisual photoreceptors in beetles seem to have a different maximum spectral sensitivity, short wavelengths in the stemmata, and long wavelengths in the LaOs and LoOs. Combined with information on the declining overall light intensity, natural twilight could be sensed as a rather sharp peak. Following the example of a butterfly, this integration of opposing spectral information may take place in the medulla. In Papilio, medulla interneurons are inhibited by short-wavelength stimuli and excited by long-wavelength stimuli (Ichikawa, 1999). A similar model twilight detector has been proposed for vertebrates, based on two classes of pineal photoreceptors (Meissl and Ekström, 1993). 
2. Scorpion lateral eyes: The scorpion visual system is obviously color-blind, as all known photoreceptors have the same spectral sensitivity (Fleissner, 1968). Twilight detection can only be achieved by evaluation of the dynamics of natural intensity changes. Based on tracing and electron microscopy, we have proposed a neuronal network providing a reafferent feedback loop system (Fleissner and Fleissner, 1998). It signals gated temporal information during dusk only, when the circadian signal in the neurosecretory efferent fibers enhances sensitivity in the median eyes (for review: Fleissner and Fleissner, 2001a). This system can only function when control channels help to distinguish adequate from inadequate time cues, i.e., discriminate between unique events and periodic light programs, or between changes of incident light induced by behavior and day/night transitions. Here the lateral eyes may be involved in several aspects: light stimuli to the lateral eyes never have induced arousal responses, which might cause phase-shifts (Fleissner et al., 1989; Fleissner and Fleissner, 2001b); lateral eyes have little circadian adaptation ( $1 \log$ unit compared to $4 \log$ units in the median eyes), thus being able to better monitor the dynamics of external light programs (Fleissner, 1977b) and also help to discriminate the rising and setting moon from dusk and dawn. Recently the metasomal light sense has been detected (Schuchardt et al., 2002), and we now believe to have in our hands an even more complete set of photoreceptors, which as a complex entity can be studied concerning the mechanisms of processing temporal information provided by the daily light cycle to the scorpion circadian pacemaker.

\section{Experimental Prerequisites for Studies on Natural Entrainment}

When dealing with mechanisms of entrainment by natural Zeitgeber stimuli, one must thoroughly think about the notion "natural": (i) For each organism the experienced light program may be different, depending on habitat, season, and physiological needs. Clearly it is different from the general day/night changes. (ii) Depending on its dioptric apparatus and photopigments and due to the animal's behavior, the receptor set-up may select specific parameters out of this external light program, modulated by adaptational processes, driven either by light or by the internal clock. (iii) Nervous processes may or may not filter specific aspects of the light program and evaluate the incoming signal as essential for the entrainment of the circadian rhythm.

Therefore, analyzing natural timing requires knowledge on the species-specific photic environment, its intensity, spectrum, and dynamics. One must also know the entire set of photoreceptors, their receptor-specific transduction processes, and their neuronal wiring to understand feedback control within the multioscillator clock system.

Laboratory experiments have shown that the circadian clock is best synchronized by light/dark transitions with intercalated twilight (scorpions: Lüttgen, 1993; hamsters: Boulos et al., 1996b; rats: Boulos et al., 1996a; mice: Kavaliers et al., 1984; even humans: Danilenko et al., 2000). This "best synchronization" means in all investigated cases, a higher precision of onset of activity, a lower threshold for entraining stimuli, and a wider range of entrainment (e.g., Lüttgen, 1993). In our scorpion studies it also showed optimized internal synchrony of different behavioral categories and a temporal pattern of behavior like that obseved in the field (Fleissner and Fleissner, 1998; Gbenro et al., 2002). 


\section{ORDER}

Nonvisual Photoreceptors in Arthropods

Thus, as another prerequisite in studies on natural entrainment, the recording of effector rhythms must allow for the expression and recognition of the complex time pattern of behavior.

As this research field is still at its beginning, we exemplify these paradigms by a pilot study program for the scorpions as a model system.

\section{The Natural Behavioral Categories}

In its natural habitat the scorpion is hidden in a burrow all day long. The clock wakes it up in the early evening, and the animal slowly approaches the exit of its burrow. Here it stays until dusk is over, then the scorpion wanders around for few hours, returns to the vicinity of the burrow where it sits and waits for bypassing prey, and reenters it, long before dawn.

\section{The Natural Light Program}

Starlight is the preferred photic surrounding for scorpion activity, total darkness for rest. In laboratory simulations, when light is not exceeding starlight, the scorpion is positive phototactic when it is awake. Moonlight, too bright for the sensitive eyes, keeps the scorpion inside the burrow. Depending on the precision of the clock controlled leaving and reentering the burrow, the scorpion might be exposed to a skeleton photoperiod with peaks during dusk and dawn, and higher light levels during night.

\section{Sensory and Neuronal Processing of the Natural Light Program}

Simultaneously with decreasing outside brightness, the median eyes become more sensitive, thus compensating for twilight transitions (in other words: masking the dynamics of twilight). This effect, evolved for optimized image processing, decreases or even extinguishes the ability to gain temporal information from twilight. The lateral eyes, when coming out of the dark burrow, have very little to do with clock controlled adaptation, rather, they adapt to the higher outside illumination by light adaptation, as does the metasomal light sense. How do these receptor systems sense time? Since the scorpion photoreceptors are color-blind, seeing time can only be achieved by perceiving the dynamics of the changing environmental brightness. A first clue to the underlying mechanisms of the optic system is derived from analyzing the peripheral neuronal network (for review: Fleissner and Fleissner, 2001a,b), and its simulation in mathematical model experiments (Friesen et al., 2001).

Well-known since 1950 (von Holst and Mittelstaedt, 1950), recognition processes make use of the reafference principle, ${ }^{\mathrm{e}}$ where the sensory system is informed on preprogrammed changes of its input. The same principle seems to be verified in scorpions:

${ }^{\mathrm{e}}$ Investigating the equilibrium system of fish, von Holst and Mittelstaedt (1950) postulated reafferent processes, which enable the organism to distinguish between externally and internally induced retinal motion. Signals that control locomotion are present in the visual system as induced retinal motion; signals that control locomotion are present in the visual system as feedback information. This reafference principle seems to be verified in many different organisms, including humans. 
The efferent circadian signal, which induces the migration of retinal shielding pigment and thus masks the twilight transition, is also delivered presynaptically to the afferent endings, and to secondary interneurons in the LA, which then "know" about the clock-controlled adaptation. So the "corrected" (unmasked) information about the twilight transitions is present in the interneurons. This efferent circadian signal is a slow-rate series of action potentials, which rises during the evening from zero to about one $1 \mathrm{~Hz}$, stays at this rate all night long, and stops in the morning. This time pattern of a "subjective twilight" can directly be compared with the unmasked dynamics of external dusk in the LA, where both signals are present as neuronal activity in second order interneurons. If subjective and unmasked external time course match, there will be no correcting output to the pacemaker; if not, a clear signal to accelerate or delay the pacemaker's phase will be produced. This hypothesis is supported by the following evidence: If the dynamics of the circadian signal are essential for this control system, then only dusk will deliver time cues and only a narrow circadian gate is open for twilight synchronization. This has been shown in multiple long-term experiments (Fleissner and Fleissner, 2002) and in mathematical model calculations (Friesen et al., 2001), and was also found in hamsters (Boulos et al., 1996b).

Input from the lateral eyes may be compared to this timing signal in the medulla, possibly correcting for time-irrelevant changes of environmental light, such as moon and clouds. Possibly also the long alarming fibers from the metasomal light sense extend up to here, avoiding photic phase-shifts of the clock by sudden light exposure during day and night. Hyperactivity, induced by light or disturbing stimuli, may phase-shift the clock via a nonphotic pathway (Fleissner and Fleissner, 2001b). But those events may gain entraining quality only when repeated and in DD, when no dusk is available as time reference. This could be shown in laboratory experiments with simulated dusk and dawn plus a superimposed moon (Fleissner and Fleissner, 1998). Though the scorpion showed an irregular locomotor activity pattern, while it tried to escape from the bright moonlight, the circadian clock kept synchronous with dusk.

When the twilight signal is absent or too low for entrainment, then the natural time pattern of behavior dissolves and ultradian activity bouts may occur. Interestingly, in experiments with slowly increasing levels of twilight intensities, behavior regains its natural time pattern before it is synchronized with the external light program (Gbenro et al., 2002). These results offer a sensitive tool to analyze natural timing mechanisms, not by simply checking whether a photic stimulus can entrain, but rather by investigating in which configuration of receptors the physiological input can detect a timing cue for the circadian clock system. Maybe, light to one receptor alone cannot be sufficient for synchronization, but only in combination with this receptor, the others gain temporal information from dusk and dawn.

\section{Hypotheses on Natural Timing Mechanisms in Color-Sensitive Systems}

For several model organisms hypotheses have been developed to understand the sensory basis for twilight recognition. Principally, most of them are based on the changing spectral composition of twilight (e.g., Meissl and Brandstätter, 1992) Photoreceptors with different spectral sensitivity may then interact to recognize twilight, like the abovedescribed extraretinal photoreceptors of beetles, also reported from the pineal. But for all these systems we do not have the experimental background to provide details on the 
neuronal basis or control of behavioral output. It seems inevitable that for all studies on entraining processes, the complexity of receptors and signaling pathways as well as behavioral and physiological output will become accepted. Results from reduced systems and laboratory situations can only be evaluated when seen as one component part of the organism in its natural surrounding.
\end{abstract}

\title{
ACKNOWLEDGMENTS
}

We gratefully acknowledge the support by our students Kirsten Schuchardt and Matthias Waterkamp, who contributed results from their doctoral theses, and Verena Ludwig, Martin Thomas, Lenka Matousek, and Thomas Gbenro, who took part in the project work during their Diploma theses. All these students were funded by the DFG priority program "Adaptive und funktionelle Mechanismen circadianer Systeme." We also thank D. Neumann (Köln), who initiated the search for the moonlight detector in Clunio, O. Friesen (Charlottesville), who made the model calculations on the feedback control of dusk detection in the scorpion, and P. DeCoursey (Columbia), who stimulated the discussions on ecological needs of species-specific specializations of twilight detection. These colleagues received DFG travel grants to cooperate in our project work. The project part on the cockroach optic lobe photoreceptors, especially concerning the cryptochrome immunocytology, was part of a common project with the teams of U. Homberg and A. Batschauer (both Marburg). We thank for receiving noncommercial antibodies against proteins of the phototransduction cascade from our colleagues B. Battelle (St. Augustine), L. Donoso (Philadelphia), T. Peichl (Frankfurt), and R. White (Boston). Our assistants, M. Stöhr, E. Nöring, and E. Thielen, deserve our gratitude for expert technical help in the laboratory and in the animal keeping house.

This project was supported by DFG grants (Fl 177/15 1-3, and 177/17 1) to G. \& G. F.

\section{REFERENCES}

Angermann, H. (1957). Über Verhalten, Spermatophorenbildung und Sinnesphysiologie von Euscorpius italicus und verwandten Arten. Z. Tierpsychol. 14:276-302.

Arikawa, K. (1999). Extraocular photoreceptors. In: Eguchi, E., Tominaga, Y., eds. Atlas of Arthropod Sensory Receptors. Tokyo-Berlin: Springer Verlag, pp. 79-86.

Ball, H. J. (1965). Photosensitivity of the terminal abdominal ganglion of Periplaneta americana. J. Ins. Physiol. 11:1311-1315.

Ball, H. J. (1972). Photic entrainment of circadian activity rhythms by direct brain illumination in the cockroach Blaberus craniifer. J. Ins. Physiol. 18:2449-2455.

Battelle, B.-A., Dabdoub, A., Malone, M. A., Andrews, A. W., Cacciatore, C., Calman, B. G., Smith, W. C., Payne, R. (2001). Immunocytochemical localization of opsin, visual arrestin, myosin III and calmodulin in Limulus lateral eye retinular cells and ventral photoreceptors. J. Comp. Neurol. 435:211-225.

Bennett, M. F. (1979). Extraocular light receptors and circadian rhythms. In: Autrum, H., ed. Comparative Physiology and Evolution of Vision in Invertebrates: Invertebrate Photoreceptors. Vol. 7/6A. Berlin-Heidelberg-New York: Springer, pp. 641-663. 
Bernal-Moreno, J. A., Miranda-Anaya, M., Fanjul-Moles, M. I. (1996). Phase-shifting the ERG amplitude circadian rhythm of juvenile crayfish by caudal monochromatic illumination. Biol. Rhythm Res. 27:299-301.

Boulos, Z., Macchi, M., Terman, M. (1996a). Twilight transitions promote circadian entrainment to lengthening light-dark cycles. Am. J. Physiol. 271(3 Pt 2):R813-R818.

Boulos, Z., Terman, J. S., Terman, M. (1996b). Circadian phase-response curves for simulated dawn and dusk twilights in hamsters. Physiol. Behav. 60(5):1269-1275.

Buma, P., Roubos, E. W., Buijs, R. M. (1984). Ultrastructural demonstration of exocytosis of neural, neuroendocrine and endocrine secretions with an in vitro tannic acid (TARI-) method. Histochemistry 80:247-256.

Calman, B. G., Lauerman, M. A., Andrews, A. W., Schmidt, M., Battelle, B. A. (1991). Central Projections of Limulus Photoreceptor cells revealed by a photoreceptorspecific monoclonal body. J. Comp. Neurol. 313(4):553-562.

Carricaburu, P. (1968). Dioptrique oculaire du scorpion Androctonus australis. Vision Res. 8:1067-1072.

Cymborowski, B., Korf, H. W. (1995). Immunocytochemical demonstration of S-antigen (arrestin) in the brain of the blowfly Calliphora vicina. Cell \& Tiss. Res. 279:109-114.

Daan, S., Aschoff, J. (2001). The entrainment of circadian rhythms. In: Turek, F., Takahashi, F. W., Moore, R. Y., eds. Handbook of Behavioral NeurobiologyCircadian Clocks. Vol. 12. New York: Kluwer Academic/Plenum Publ., pp. 7-44.

Danilenko, K. V., Wirz-Justice, A., Krauchi, K., Weber, J. M., Terman, M. (2000). The human circadian pacemaker can see by the dawn's early light. J. Biol. Rhythms 15:437-446.

Edwards, D. H. Jr. (1984). Crayfish extraretinal photoreception. I. Behavioral and motoneuronal responses to abdominal illumination. J. Exp. Biol. 109:291-306.

Fahrenbach, W. H. (1975). The visual system of the horseshoe crab. Intl. Rev. Cytol. 41:285-349.

Felisberti, F., Ventura, D. F. (1996). Cerebral extraocular photoreceptors in ants. Tissue \& Cell 28:25-30.

Fleissner, G. (1968). Untersuchungen zur Sehphysiologie der Skorpione. Verh. DZG 61:375-380.

Fleissner, G. (1974). Über die Sehphysiologie von Skorpionen. Ph.D. thesis, J. W. GoetheUniversität, Frankfurt am Main.

Fleissner, G. (1977a). The absolute sensitivity of the median and lateral eyes of the scorpion, Androctonus australis L. (Buthidac, Scorpiones). J. Comp. Physiol. 118:109-120.

Fleissner, G. (1977b). Differences in the physiological properties of the median and the lateral eyes and their possible meaning for the entrainment of the scorpion's circadian rhythm. J. Interdiscipl. Cycle Res. 8:15-26.

Fleissner, G. (1977c). Scorpion lateral eyes: extremely sensitive receptors of Zeitgeber stimuli. J. Comp. Physiol. 118:101-108.

Fleissner, G. (1982). Isolation of an insect circadian clock. J. Comp. Physiol. A 149:311-316.

Fleissner, G. (1985). Intracellular recordings of light responses from spiking and nonspiking cells in the median and lateral eyes of the scorpion. Naturwiss. 72:46. 


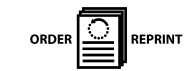

Fleissner, G., Siegler, W. (1978). Arhabdomeric cells in the retina of the median eyes of the scorpion. Naturwissenschaften 65:210-211.

Fleissner, G., Fleissner, G. (1985). Neurobiology of a circadian clock in the visual system of scorpions. In: Barth, F. G., ed. Neurobiology of Arachnids. Berlin-HeidelbergNew York: Springer Verlag, pp. 351-375.

Fleissner, G., Fleissner, G. (1998). Natural photic Zeitgeber signals and underlying neuronal mechanismsm scorpions. In: Touitou, Y., ed. Biological ClocksMechanisms and Applications. Paris: Elsevier, pp. 171-180.

Fleissner, G., Fleissner, G. (2001a). Neuronal organization of circadian systems. In: Brownell, P., Polis, G., eds. Scorpion Biology and Research. Chap. 4. New York: Oxford University Press, pp. 107-137.

Fleissner, G., Fleissner, G. (2001b). The scorpion's clock, feedback mechanisms in circadian systems. In: Brownell, P., Polis, G., eds. Scorpion Biology and Research. Chap. 5. New York: Oxford University Press, pp. 138-158.

Fleissner, G., Fleissner, G. (2002). Perception of natural Zeitgeber signals. In: Kumar, V., ed. Biological Rhythms. New Delhi/New York: Narosa/Springer, pp. 85-95.

Fleissner, G., Fleissner, G., Hohmann, W. (1989). Locomotor activity inverses the phase shifting effect of light on the circadian system of scorpions. In: Neuronal Mechanisms of Behaviour. Göttingen: Thieme Verlag, p. 256.

Fleissner, G., Fleissner, G., Frisch, B. (1993a). A new type of putative non-visual photoreceptors in the optic lobe of beetles. Cell Tiss. Res. 273(3):435-445.

Fleissner, G., Gehrmann, S., Volhardt, H., Fleissner, G. (1993b). The newly discovered photoreceptors in the beetles optic lobe - a photoneuroendocrine system? Neurobiology Conference. Göttingen: Thieme Verlag, p. 274

Fleissner, G., Fleissner, G., Nink, V., Volz, A. (1994). An extraretinal photoreceptor system in the optic lobes of beetles and their pupae - its ontogeny, functional compartments and possible physiological meaning. Proc. SRBR 4:94.

Fleissner, G., Vollhardt, H., Volz, A., Nink, V., Fleissner, G. (1995). Photoreceptive and endocrine compartments in the extraretinal photoreceptive organs in the beetle's optic lobe. In: Learning and Memory. Göttingen: Thieme Verlag, p. 326.

Fleissner, G., Waterkamp, M., Thomas, M., Fleissner, G. (1998). Fine-structural differences between the two types of extraretinal photoreceptors in the Tenebrionid beetle, Zophobas atratus (morio) (B) The lamina and lobula-organs. Proc. 26th Göttingen Neurobiol. Conf. Göttingen: Thieme Verlag, p. 275.

Fleissner, G., Loesel, R., Waterkamp, M., Kleiner, O., Batschauer, A., Homberg, U. (2001). Candidates for extraocular photoreceptors in the cockroach suggest homology to the lamina and lobula organs in beetles. J. Comp. Neurol. 433(3):401-414.

Friesen, W. O., Fleissner, G., Fleissner, G. (2001). Role of feedback loops in the scorpion circadian system. Neurocomputing 38-40:607-614.

Frisch, B., Fleissner, G., Brandes, C., Hall, J. C. (1996). Staining in the brain of Pachymorpha sexguttata mediated by an antibody against a Drosophila clockgene product: labeling of cells with possible importance for the beetle's circadian rhythms. Cell Tiss. Res. 286(3):411-429.

Gao, N., Schantz, M. von, Foster, R. G., Hardie, J. (1999). The putative brain photoperiodic photoreceptors in the vetch aphid, Megoura viciae. J. Insect Physiol. 45:1011-1019. 
Gbenro, T., Fleissner, G., Busch, S., Fleissner, G. (2002). Monitoring behavioral categories show internal synchronization better than records of unspecified locomotor activity. Proc. 8th Meeting SRBR: 8:184.

Geethabali. (1974). Neurophysiological studies on the central nervous system of scorpion. Ph.D. thesis, Bangalore University, India.

Geethabali, Rao, K. P. (1972). A metasomatic neural photoreceptor in the scorpion. J. Exp. Biol. 58:189-196.

Gielbultowicz, J. M., Bell, R. A., Imberski, R. B. (1988). Circadian rhythm of sperm movement in the male reproductive tract of the gypsy moth Lymantria dispar. J. Insect Physiol. 34:527-532.

Gielbultowicz, J. M., Riemann, J. G., Raina, A. K., Ridgway, R. L. (1989). Circadian system controlling release of sperm in the insect testes. Science 245:1098-1100.

Gilbert, C. (1994). Form and function of stemmata in larvae of holometabolous insects. Annu. Rev. Entomol. 39:323-349.

Goodman, L. J. (1981). Organisation and physiology of the insect dorsal ocellar system. In: Autrum, H. J., ed. Invertebrate Visual Centers and Behavior II. Vol. VII/6c. Berlin, Heidelberg, New York: Springer Verlag, pp. 201-286

Hagberg, M. (1986). Ultrastructure and central projections of extraocular photoreceptors in caddiesflies (Insecta, Trichoptera). Cell Tiss. Res. 245:634-648.

Hama, K. (1961). A photoreceptor-like structure in the ventral cord of crayfish, Cambarus virilis. Anat. Rec. 140:329-336.

Hanna, W. J. B., Pinkhasov, E., Renninger, G. H., Kaplan, E., Barlow, R. B. Jr. (1985). The tail of Limulus contains photoreceptors that modulate a circadian clock. Biol. Bull. 169:552.

Hege, D. M., Stanewsky, R., Hall, J. C., Gielbultowcz, J. M. (1997). Rhythmic expression of a PER-reporter in the Malpighian tubules of decapitated Drosophila: evidence for a brain-independent circadian clock. J. Biol. Rhythms 12:300-308.

Helfrich-Foerster, C., Engelmann, W. (2002). Photoreceptors for the circadian clock of the fruitfly. In: Kumar, V., ed. Biological Rhythms. Delhi (India): Narosa Publishing House, pp. 94-106.

Hofbauer, A., Buchner, E. (1989). Does Drosophila have seven eyes? Naturwissenschaften 76:335-336.

Holst, E. V., Mittelstaedt, H. (1950). Das Reafferenzprinzip. Naturwissenschaften 37:464-476.

Ichikawa, T. (1991). Brain photoreceptors in the adult and pupal butterfly: fate of larval ocelli. Zoological Science 8:471-476.

Ichikawa, T. (1999). Photoreceptor organs other than compound eyes. I. Stemmata. In: Eguchi, E., Tominaga, Y., eds. Atlas of Arthropod Sensory Receptors. Tokyo-Berlin: Springer Verlag, pp. 47-54.

Kavaliers, M., Hirst, M., Teskey, G. G. (1984). Aging and daily rhythms of analgesia in mice: effects of natural illumination and twilight. Neurobiol. Ageing 5:111-114.

Kennedy, D. (1958). Responses from the crayfish caudal photoreceptor. Am. J. Ophthal. 46:19-26.

Kjellesvig-Waering, E. N. (1986). A restudy of the fossil Scorpionida of the world. Palaeontogr. Am. 55.

Koehler, W., Fleissner, G. (1978). Internal desynchronisation of bilaterally organized circadian oscillators in the visual systems of insects. Nature 274:708-710. 


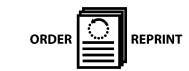

Korf, H. W. (1994). The pineal organ as a component of the biological clock: phylogenetic and ontogenetic considerations. Ann. NY Acad. Sci. 719:13-42.

Locket, A. (2001). Eyes and vision. In: Brownell, P., Polis, G., eds. Scorpion Biology and Research. New York: Oxford University Press, pp. 79-106.

Loesel, R., Homberg, U. (2001). Anatomy and physiology of neurons with processes in the accessory medulla of the cockroach Leucophaea maderae. J. Comp. Neurol. 439:193-207.

Lüttgen, M. A. (1993). Entrainment der circadianen Laufrhythmik durch Lichtzeitgeber: Untersuchung biologisch relevanter Lichtparameter am Beispiel der Lokomotionsrhythmik von Androctonus australis L. (Scorpiones, Buthidae). J. W. GoetheUniversität: Frankfurt am Main.

Meissl, H., Brandstätter, R. (1992). Photoreceptive functions of the teleost pineal organ and their implications in biological rhythms. In: Ali, M. A., ed. Rhythms in Fishes. New York: Plenum Press, pp. 235-254.

Meissl, H., Ekström, P. (1993). Extraretinal photoreception by pineal systems: a tool for photoperiodic time measurements? Trends Comp. Biochem. Physiol. 1:1223-1240.

Melzer, R. R., Paulus, H. F. (1989). Evolutionary pathways to the larval eyes of insects, higher dipteran stemmata and the evolutionary development of the Bolwig's organ. Z. Zool. System. Evolutionsforsch. 27:200-245.

Menaker, M. (1982). The search for principles of physiological organization in the vertebrate circadian system. In: Aschoff, J., Daan, S., Groos, G., eds. Vertebrate Circadian Systems. Berlin-Heidelberg: Springer Verlag, pp. 1-12.

Mischke, U., Wellmann, H. (1985). The ultrastructure of ocular and extraocular photoreceptors in Colorado potatoe beetles (Chrysomelidac: Leptinotarsa decemlineata). Verh. DZG 78:291.

Mischke, U., Ziegler, R. (1987). Translokation von Photorezeptoren bei der postembryonalen Gehirnentwicklung von Manduca sexta. Verh. DZG 80:150.

Miyako, Y., Arikawa, K., Eguchi, E. (1993). Ultrastructure of the extraocular photoreceptor in the genitalia of a butterfly, Papilio xuthus. J. Comp. Neurol. 327:458-468.

Mizoguchi, A., Ishizaki, H. (1984). Further evidence for the presence of a circadian clock in the prothoracic glands of the saturnid moth Samiacynthia ricini: decapitated larvae can respond to light-changes. Development, Growth and Differentiation 26:607-611.

Mizunami, M. (1995). Organization of ocellar pathways in the cockroach brain. J. Comp. Neurol. 352:458-468.

Nässel, D. R., Holmquist, M. H., Hardie, R. C., Häkanson, R., Sundler, F. (1988). Histamine-like immunoreactivity in photoreceptors of the compound eyes and ocelli of the flies, Calliphora erythrocephala and Musca domestica. Cell Tiss. Res. 253:639-646.

Nelson, D., Takahashi, J. (1991). Sensitivity and integration in a visual pathway for circadian entrainment in the hamster. J. Physiol. 439:115-145.

Neumann, D. (1989). Circadian components of semilunar and lunar timing mechanisms. In: Daan, S., Gwinner, E., eds. Biological Clocks and Environmental Time. New York-London: The Guildford Press, pp. 173-182.

Page, T. L. (2001). Circadian system of invertebrates. In: Takahashi, J., Turek, F., Moore, F., Moore, R. Y., eds. Hb. Behav. Neurobiol: Circadian Clocks. Vol. 12. New York: Kluwer Academic/Plenum Publ., pp. 79-110. 
Plantz, J. D., Kaneko, M., Hall, J. C., Kay, S. A. (1997). Independent photoreceptive circadian clock throughout Drosphila. Science 278:1632-1635.

Renninger, G. H., Chamberlain, S. C. (1993). Modulation of photoreceptor function in Limulus polyphemus by a central circadian clock. In: Wiese, K., Gribakin, F. G., Popov, A. V., Reninnge, G., eds. Sensory Systems of Arthropods. Basel-BostonBerlin: Birkhäuser Verlag, pp. 307-316.

Sandeman, D. C., Sandeman, R. E., de Couet, H. G. (1990). Extraretinal photoreceptors in the brain of the crayfish Cherax destructor. J. Neurobiol. 21:619-629.

Schliwa, M., Fleissner, G. (1979). Arhabdomeric cells of the median eye retina of scorpions. J. Comp. Physiol. 130:265-270.

Schliwa, M., Fleissner, G. (1980). The lateral eyes of the scorpion, Androctonus australis. Cell Tiss. Res. 206(1):95-104.

Schuchardt, K., Fleissner, G., Fleissner, G. (2002). Histological and immunocytochemical evidence for a metasomal light sense in scorpions. Proc. Meeting 8th SRBR: 254.

Schultz, W. D., Schlüter, U., Seifert, G. (1984). Extraocular photoreceptors in the brain of Epilachna varivestis (Coleoptera Coccinellidae). Cell Tiss. Res. 236:317-320.

Schwemer, J. (1985). Turnover of photoreceptor membrane and visual pigment in invertebrates. Dahlem Konferenzen., Berlin: Springer: 303-326.

Seifert, P., Smola, U., Schinko, I. (1987). Internal extraocular photoreceptors in a Dipteran insect. Tissue \& Cell 19:111-118.

Sprint, M. M., Eaton, J. L. (1987). Flight behavior of normal and anocellate cabbage loopers (lepidoptera: Noctuidae). Ann. Entomol. Soc. Am. 80:468-471.

Thomas, M. A., Fleissner, G., Hauptfleisch, S., Lemmer, B. (2003). Subcellular identification of angiotensin II- and angiotensin II (AT1)-receptor-immunoreactivity in the central nervous system of rats. Brain Research 962:92-104.

Truman, J. (1976). Extraretinal photoreception in insects. Photophysiology 23:215-225.

Vafopoulou, X., Steel, C. G. (1996). Circadian regulation of a daily rhythm of release of prothoracicotropic hormone from the brain retrocerebral complex of Rhodnius prolixus (hemiptera) during larval-adult development. Gen. Comp. Endocr. 102:123-129.

Waterkamp, M., Fleissner, G., Thomas, M., Fleissner, G. Fine-structural differences between the two types of extraretinal photoreceptors in the Tenebrionid beetle, Zophobas atratus (morio) (A) The stemmata. Proc. 26th Göttingen Neurobiol. Conf., Göttingen: Thieme Verlag, p. 274.

Wunderer, H., De Kramer, J. J. (1989). Dorsal ocelli and light-induced diurnal activity patterns in the arctiid moth Creatonotus transiens. J. Insect Physiol. 35:87-95.

Yasuyama, K., Meinertzhagen, I. A. (1999). Extraretinal photoreceptors at the compound eye's posterior margin in Drosophila melanogaster. J. Comp. Neurol. 412(2):193-202.

Yoshida, M. (1979). Extraocular photoreception. In: Autrum, H. J., ed. Comparative Physiology and Evolution of Vision in Invertebrates: Invertebrate Photoreceptors. Vol. 7/6A. Berlin, Heidelberg, New York: Springer Verlag.

Zwicky, K. T. (1968). A light response in the tail of Urodacus, a scorpion. Life Sci. 7:257-262.

Zwicky, K. T. (1970). Behavioural aspects of the extraocular light sense of Urodacus, a scorpion. Experientia 26:747-748. 
Copyright $\odot 2003$ EBSCO Publishing 